\title{
How to manage senior employees? Theories and current fields of research in an organizational context
}

\author{
Tanja Kosowski*
}

Purpose: The greying of the workforce is a globally discussed phenomenon. It gained importance for organizations, policy-makers and scholars alike. This article offers an overview of applied theories and fields of research pertaining to the discussion on senior employees in the workforce. It presents current managerial practices for senior employees and assesses factors for the employability of senior employees in an organization.

Design/methodology: The paper is based on a review of recent academic articles published in peer-reviewed journals. Keywords and elimination criteria are explained in the corresponding section.

Findings: The article incorporates studies on senior employees from various disciplines in the field of organizational research. It portrays leading streams of thought on the employability of senior workers (e.g. depreciation/conservation model, standard economic theory and human capital theory). Moreover, it elaborates organizational factors which affect the employability of this cohort (e.g. motivators and demotivators for senior employees)

Research limitations/implications: The article discusses the field of organizational research and related factors. Therefore, it is limited to studies concerning the field of organizational research. Economic, social or individual influences also constitute an important topic which should be investigated and discussed.

Originality/value: The article presents the first review of theories and fields of research on senior employees in organizations and connects job and organizational factors which influence the employment situation of senior employees in an organization. The review encourages a dialogue regarding senior employees from various disciplines.

Keywords: senior employees, greying workforce, ageing workforce, age diversity management, inclusive workplaces.

Submitted: 09.10.18 | Accepted: 13.12.18

\section{Jak zarządzać pracownikami dojrzałymi? Teorie i aktualne obszary badawcze w kontekście organizacji}

Cel: Starzenie się sity roboczej jest globalnie omawianym zjawiskiem, problemem, który zyskat na znaczeniu $w$ przypadku zarówno organizacji, ustawodawców, jak i badaczy. Autorka dokonuje przegladu stosowanych teorii $i$ obszarów badawczych $w$ ramach debaty na temat pracowników dojrzatych wykorzystywanych jako siła robocza. Przedstawia aktualne praktyki

\footnotetext{
Tanja Kosowski - Kozminski University.

Correspondence address: Kozminski University, Department of Management, 59 Jagiellońska St., 03-301 Warsaw, Poland, e-mail: tkosowski@kozminski.edu.pl.
} 
zarzadzania pracownikami dojrzatymi i czynniki dostępności $w$ zakresie możliwości zatrudniania pracowników dojrzałych $w$ organizacjach.

Projekt/metodologia: Artykut opiera się na przegladzie najnowszych artykutów naukowych opublikowanych $w$ recenzowanych czasopismach. Wodpowiedniej części wyjaśniono stowa kluczowe i kryteria eliminacyjne.

Wnioski: Artykut przedstawia wyniki badań na temat pracowników dojrzatych, prowadzonych w ramach różnych dyscyplin $w$ obszarze badań nad organizacja. Przedstawia najważniejsze trendy w badaniach nad możliwościa zatrudniania pracowników dojrzatych (np. model deprecjacji/konserwacji, standardowa teoria ekonomiczna i teoria kapitału ludzkiego). Ponadto omawia czynniki organizacyjne, które wptywaja na możliwość zatrudniania takich jednostek (np. pozytywne/negatywne czynniki organizacyjne i zawodowe).

Ograniczenia badawcze/implikacje: Artykut przedstawia obszary badań nad organizacja i powiazanych czynników. Dlatego też ogranicza się do obszaru badań organizacji. Wpływy ekonomiczne, społeczne czy indywidualne stanowia ważna kwestię, która należy zbadać i omówić.

Nowatorski charakter/wartość pracy: Artykut jest pierwszym przegladem teorii i obszarów badawczych na temat pracowników dojrzałych w organizacjach; taczy czynniki zawodowe i organizacyjne, które wplywaja na sytuację dotyczaca zatrudnienia pracowników dojrzałych $w$ organizacji. Przeglad ten zachęca do dialogu na temat pracowników dojrzałych $w$ ramach różnych dyscyplin.

Słowa kluczowe: dojrzali pracownicy, sędziwi pracownicy, starzejąca się siła robocza, sędziwa, przedłużenie okresu aktywności zawodowej.

Nadesłany: 09.10.18 | Zaakceptowany do druku: 13.12.18

JEL: M12

\section{Introduction}

The global issue of ageing workforce is of key interest to European policymakers. This phenomenon will continue to generate considerable economic and social challenges in the coming years. It confronts European members with similar problems. The debates focus on labour skill shortage, adequacy and maintenance of the social security system, and an age-related reduction of productivity and innovation (ILO 2013; Serban Andreea Claudia, 2012). To counteract these problems, policies in the European Union (EU) have concentrated on increasing the employment proportion among people in the age bracket of 55-64 years, reducing incentives for retirement, and postponing the retirement age in member countries. Therefore, in 2013, the 28-member states formulated the EU 2020 strategy and set the aim of having $50 \%$ of their people active in the labour market in the cohort of individuals aged 55-64 years. Yet, differences among EU countries in the employment level of senior employees are primarily based on national legislation and social aspects (e.g. work-related values, cultures, and traditions). Overall, Eastern countries have a lower workforce participation among this age group compared to Western countries (Eurostat, 2017).

For industrialized countries, the labour market performance of senior employees is of particular relevance for the future. In most countries, the population is definitely shrinking, and so is the labour force. In Poland, the ageing of the population is projected to have a pronounced impact. Today, Poland is one of the EU countries with a low proportion of elderly people (20\% in 2012), but the ratio of the population aged above 65 years to the population aged 20-64 years is projected to triple by 2050 . By this time, Poland will have moved to the group of member states with an above-average ratio (OECD, 2015). In addition, middle-aged workers - those who will become senior employees of the future - are not only a strong cohort, but their average skill levels are also higher compared to older cohorts. Thus, the availability of senior workers will be of increased importance for the labour mar- 
ket in the coming years. Yet, large sections of SME entrepreneurs are still in the planning phase and more progress needs to be made in the coming years to adapt to a transforming labour force. This is especially the case as there is evidence that high proportions of senior employees are already even more commonly employed in SMEs. Moreover, entrepreneurs seem to demonstrate an overall positive attitude towards senior employees. They not only appreciate the advantages of older workers but also dismiss commonly believed drawbacks concerning senior employees (KfW, 2014). This article aims to encourage discussion on this issue and prompt action among entrepreneurs to prepare for a greying workforce.

The management of senior employees is widely discussed in literature. According to Kooij et al. (2014), the discussion on how to manage senior employees is focused on the proposition of appropriate HR practices to employ senior workers or on the examination of such practices to ensure the workers' retention (Kooij et al., 2014). Therefore, many research studies from various disciplines have concentrated on this issue. The field of research studies in organizational research builds on different theories and concepts which co-evolved and co-exist. This article gives an overview of theories to serve as a foundation for discussion on the employment of senior employees and indicates identified factors which underpin the employability of senior employees in an organization. Research studies included in this article have provided evidence suggesting that policies such as flexibility, tailored training and development programs, modifications of job characteristics, and design boost workforce participation of senior employees.

\section{Senior employees in organizational research}

Age categories in organizational research vary to a greater extent than the categories used by policymakers or institutions. Research often defines senior employees in an extremely imprecise manner, ranging anywhere from 40 to 65 years old and over (e.g. Turek and Perek-Bialas, 2013; Beehr and Bennett, 2015). Similarly, some research lacks the presence of any age metric, simply comparing "young employees" to "senior employees". Studies utilizing such discourse frequently address issues pertaining to performance, age discrimination, or the well-being of employee groups. The term mature-aged employee is rather cloudy in terms of a precise age marker. Several age brackets and barriers are applied and maintained in the current literature.

\subsection{Identifying relevant literature}

The term mature-aged employee is a complex one with diverse interpretations among scholars. To get an overview of existing research studies pertaining to the field of senior employees, several keywords which are used interchangeably for the term senior employees have been used. A systematic literature review on senior employees in organizational research was conducted. The research was divided into four phases consisting of database selection, keyword identification, article selection, and literature analysis with elimination criteria allowing to focus on the key research area (Czakon, 2011). In the process of keyword identification, useful feedback related to several subject keywords and those in abstracts ratio allowed for the identification of the most commonly used phrases.

Figure 1 displays the logic applied to identify relevant publications. The main database for conducting the literature research was the SCOPUS database. Further articles came from the Clarivate database (formerly Web of Science). In the latter source, the keyword search was sorted according to citation account. Thirty most cited articles have been included for further review. As the term mature-aged employee is not precisely defined, a combination of synonyms were applied to retrieve literature. The identified journal articles were limited to publications in the English language in peer-reviewed journals in Europe. Further analysis of abstracts, titles, subject keywords, and finally the full text in case of any doubts allowed the number of articles to be limited. At a later stage of the literature review, further articles were selected and added to the final list of sources using a snowballing technique. Overall, a final list of 134 articles coming from three different sources (SCOPUS: 94; Clarivate Analytics: 27 and snowballing technique: 13 ) have been reviewed. 


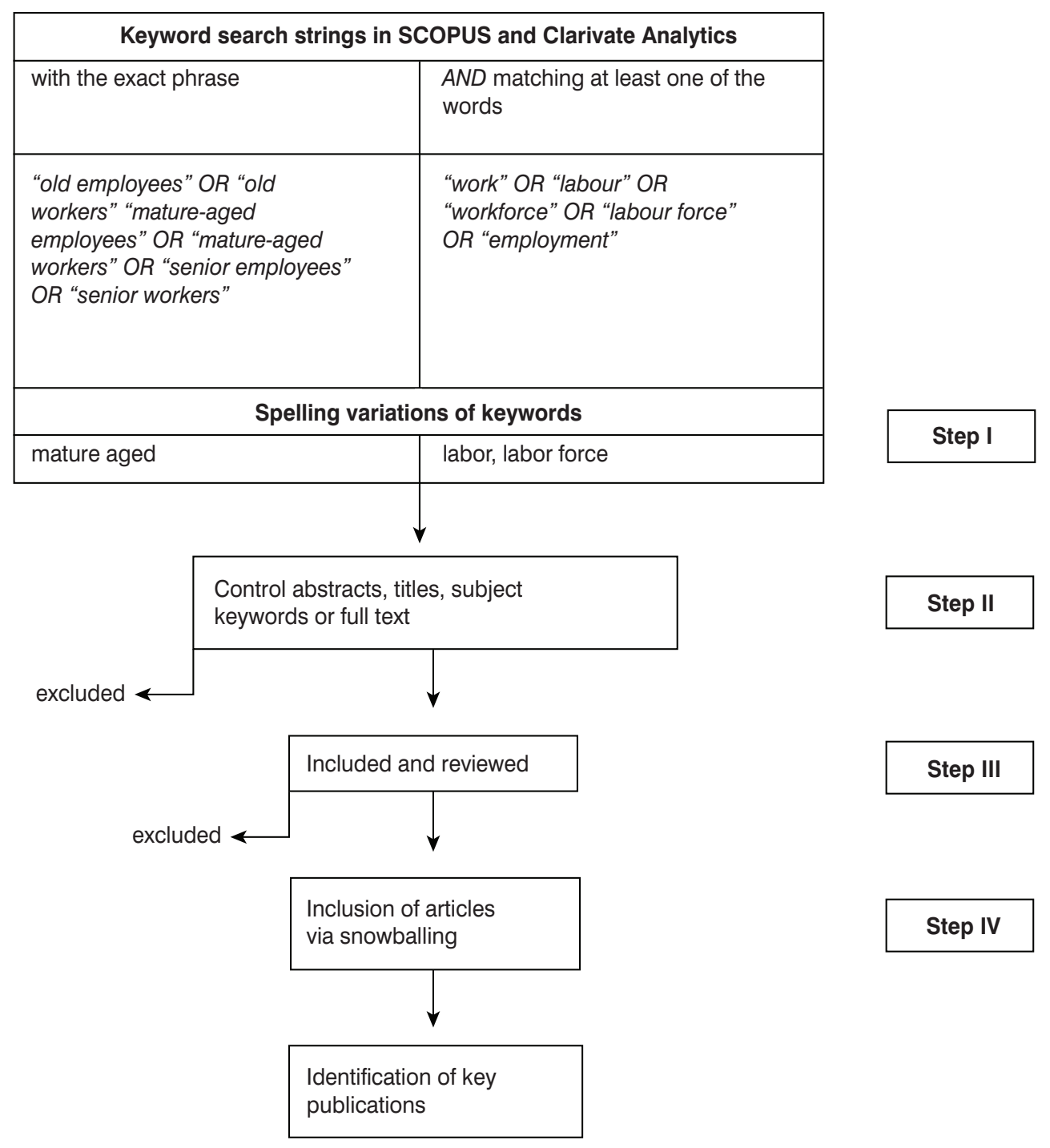

Source: own elaboration.

The 20 most cited publications arranged in chronological order might loom over the development of research on senior employees and can be summarized by their themes: (1) research on generational differences, (2) the issue of a greying workforce, (3) specifics and characteristics of senior employees, (4) ageism \& stereotypes, (5) soft elements of the employability of senior employees (e.g. psychological contract and work values).

\subsection{Relevant theories in the discussion of senior employees}

Discussions regarding the employment situation of senior employees involve one out of three economic theories: Depreciation / Conservation model, Standard Economic Theory and Human Capital Theory. The first one can be divided into two differ- ent research streams. In one stream, older workers are encouraged to leave the labour market, as it is believed that their value to the organization decreases over time. The second stream takes the opposite stance and argues for an increasing value of senior employees for the organisation. Standard economic theory is rather used in discussions pertaining to topics such as ageing, productivity and wages. On the other hand, human capital theory serves as a basis for discussions regarding age, stereotypes and discrimination.

\section{Standard economic theory}

Standard economic theory assumes that the actual labour demand is defined over the (relative) labour price, capital and technology used during the production process. According to this theory, labour price 
and labour productivity are closely related (Hamermesh 1993; van Dalen, Henkens and Schippers, 2009). However, Thurow (1975) was among the first to point out that even though they are related, they are not analogical. He called this phenomenon an implicit contract. The implicit contract describes the understanding that earnings and productivity vary during the course of one's life. Following his argumentation, employees get a seniority premium in their later career life.

Thurow explains that at the beginning of a person's career, they accept that their earnings do not reflect their productivity level, whereas they profit during the second phase of their career in which their wage is higher than their productivity. Thurow (1975) further argues that the seniority premium offers an incentive to prolong one's working life. This theory is also proffered by various other scholars, among them Lazear (1979) and the so-called Lazear Contracts (e.g. Mincer, 1958). In some research studies, this phenomenon is also described by the term "seniority rules" (e.g. Hutchens, 1987; Dustmann and Meghir, 2003). The trouble caused by these implicit contracts is that this type of implicit contract between employee and employer is hampered by an ageing population as seniority premiums appear to be a large burden for employers. In the past, employers were able to compensate for seniority premiums by having a relatively young population age (young population $>$ elderly population) and by enjoying a gain over having a greater share of young employees in relation to senior employees. Facing an ageing population (elderly population > young population), employers need to absorb increased staff costs caused by relatively higher seniority premiums (Krecker, 1994). Just as the gap between young and senior employees is going to increase, the gap between wage-productivity dividends and premiums is going to increase too. Organizations located in countries severely hit by the ageing of the population will find themselves in an intense struggle to survive, facing organizations from countries less affected by an ageing population (van Dalen et al., 2009).

In conclusion, according to standard economic theory, the main consequence resulting from an ageing workforce for organizations is increasing staff costs caused by seniority premiums in the later stage of their employees' careers. The increased seniority premiums are caused by a wider demographic gap between young and senior individuals and an increased gap between young and senior workers.

\section{Human capital theory}

In human capital theory, productivity is the sum of one's initial education and one's acquired experience. When hiring an employee, however, employers can never be sure of their actual productivity. According to Phelps (1972), employers therefore rely on statistical information on the behaviour and development of employee cohorts. Research has demonstrated that criteria which are frequently applied by employers in the selection process are indeed those which are preexisting, like gender, social background, ethnicity or age (Van Beek et al., 1997). Becker (1957) found that using such criteria apparently disadvantages certain groups. A vast amount of research studies (e.g. Bilett et al., 2011) observed prevailing negative stereotypes among employers regarding the productivity of senior employees. Stereotypes, although they may partly be an accurate representation of reality, may handicap senior employees on the basis of inaccurate assumptions about members of their age group (Hilton and Von Hippel, 1996). Stereotypes regarding not only the productivity of senior employees, but also their adaptability, methods of work and technical understanding are prevalent (Henkens, 2005). Some stereotypes even direct senior employees' personal lives, assuming that senior employees should retire early and enjoy their well-earned retirement phase (Joulain and Mullet, 2001; McCann and Giles, 2003; Van Dalen and Henkens, 2005). In cases where work performance is low and the costs of an employee group are high, the employer faces a "wage-productivity gap" (Turek and Perek-Bialas, 2013; Flabbi and Ichino, 2001). However, such a possible wage-productivity gap is predominantly rejected by entrepreneurs, with $42 \%$ of entrepreneurs disagreeing with this assumption (KfW, 2014). They admit that such seniority-based pay has sectorial differences. In knowledge-intensive services or manufacturing which involves a greater extent of $\mathrm{R} \& \mathrm{D}$, the expertise of senior employees is seen as particularly valuable. 
Firms from the construction sector are more sceptical about senior employees as the work is typically physically demanding.

All in all, a predicted wage-productivity gap which could be expected by applying human capital theory to a greying workforce is mostly unsupported by company owners. However, one should acknowledge that the occurrence of such a wage-productivity gap is subject to sectorial differences. For knowledge-based work, the gap seems to be less pronounced than for physical work environments.

\section{Depreciation/Conservation model}

From the perspective of management, more attention in research is being placed on how a sustainable workforce can be developed and maintained (Hertel et al., 2013; Wang and Schultz, 2010), especially with regard to different life-stages (Edwards et al., 2006; Rudolph, de Lange and van der Heijden, 2014). Yeatts et al. (2000) distinguish two different philosophies about senior employees. One is the depreciation model, which assumes that older workers lose their value and should be encouraged to leave the organization. The conservation model takes the opposite standpoint. This model assumes that senior employees are a renewable asset that continues to be valuable if managed properly. Building on the second model, namely the conservation model, researchers try to develop certain practices to manage senior employees. Paul and Townsend (1993), for example, advised reconsidering existing managerial practices and introducing part-time work, flexible work schedules, voluntary demotions, flexible benefits and reduced shifts, as well as career-long training to retain senior employees in an organization. Other scholars (e.g. ArmstrongStrassen, 2008; Rau and Adams, 2005; Remery et al., 2003) suggested specific training programs, a reduced workload, sabbatical leaves, participation in decisionmaking and additional leaves as important managerial practices for senior employees.

The depreciation/conservation model is the basis for defining managerial practices which help to reform the situation of senior employees in an organization. As already mentioned, entrepreneurs generally regard senior employees as more resilient and value them for their expertise. Therefore, actions to prepare for a changing labour force may emanate from the managerial practices discussed here. Among these managerial practices, it is possible to distinguish between job (flexible job design options, training and development) and organization (ergonomically designed workplaces, ageism, positive and negative stereotypes, organizational support and inclusion) related factors.

\subsection{Factors which impact the employability of senior employees}

The conducted review of literature has identified several useful managerial practices towards the cohort of senior employees. The body of literature mostly appeared in the field of Human Resource Management (HRM) as its practices may be important for the employment of senior employees. This section discusses in detail different managerial practices which are considered beneficial to senior employees and are frequently indicated by the literature. The literature provides evidence that several managerial practices motivate senior employees to continue working (Cleas and Heymans, 2008; Armstrong-Stassen, 2008).

\section{Motivators for senior employees}

\section{FLEXIBLE WORK DESIGN}

Regardless of age, flexibility is a preference for today's workforce. Besides, research demonstrates that flexible work options have an important impact on the prolongation of working life for senior employees (Herrbach et al., 2009; van der Heijden et al., 2008; Wang and Schultz, 2010). Overall, the term "workplace flexibility" has not been fully defined. The term is used to describe flexible workplace schedules (compressed working weeks, flexible hours), remote working options (home-office, telework), part-time, jobsharing and intermittent work (seasonal employment, project related work), career breaks, unpaid short- or long-term leaves, as well as phased retirement programs (Eversole et al., 2012; Appannah and Biggs, 2015). A study by Montenegro et al. (2002) found an increasing number of reasons why older workers would continue to work longer which are of a non-financial character. According to their study, a frequently mentioned reason why people would consider working further is the extent to which 
an organization would accommodate to their flexibility needs.

However, these non-financial reasons (e.g. "have something interesting to do," "work for enjoyment," "stay physically active") often interfere with an employee's interest to meet family demands or to provide an employee more leisure time. Hence, research has overwhelmingly demonstrated that flexible work options (schedules and hours) and part-time work seem to be of the highest importance to senior employees (Montenegro et al., 2002; Rau and Adams, 2005). Another study conducted by Buyens et al. (2007) focused on assessing the preferred working situation of older workers. Their study brought to light three important results. It shows that older workers prefer to work less or part-time over reducing responsibilities or workload. Senior workers' main career-extending preferences are to enhance their own expertise and coach or train younger colleagues. The third group measured career-preservation preferences and indicated that senior workers in general wish to keep their current position, therefore showing that they usually feel comfortable in their current jobs. A further concept belonging to flexible work designs options is the concept of "flexicurity". According to Wilthagen (2001) it can be regarded as a positive sum game in bargaining on flexibility and job security. It is worth mentioning that the flexicurity concept is not coercively promoting a prolongation of working life. Indeed, one could possibly argue that early retirement schemes are used to replace senior workforce with younger counterparts. However, this concept also allows for different possibilities, combining flexibility and security. Table 1 shows possible flexicurity options.

Table 1.

\begin{tabular}{|l|l|l|l|}
\hline Security/Flexibility & \multicolumn{1}{|c|}{ Income security } & \multicolumn{1}{|c|}{ Job security } & \multicolumn{1}{|c|}{ Employment security } \\
\hline Numerical/external & $\begin{array}{l}\text { Early retirement } \\
\text { option }\end{array}$ & $\begin{array}{l}\text { Mediation to other } \\
\text { firms, self-employment } \\
\text { option, Cooperation } \\
\text { with temp agencies }\end{array}$ \\
\hline Numerical/internal & Functional/internal & $\begin{array}{l}\text { Part-time work, } \\
\text { reduced working hours }\end{array}$ & Part-time retirement \\
\hline & $\begin{array}{l}\text { Reduced workload, } \\
\text { task/job rotation, } \\
\text { reduction of } \\
\text { inconvenient working } \\
\text { hours }\end{array}$ & $\begin{array}{l}\text { Job rotation, bridge } \\
\text { employment }\end{array}$ \\
\hline
\end{tabular}

Source: adapted from Tros (2005).

What might attract attention is that the concept of flexicurity (Table 1) and flexible job design options (compressed working weeks, flexible hours, remote working options, part-time, job-sharing and intermittent work, career breaks, and phased retirement) are overlapping in their practices. This interference could be explained by the aforementioned fact that the term "flexibility" in a work-setting lacks an accepted definition.

\section{Training \& DeVELOPMENT OPTIONS}

According to Fuller et al. (2005), it is necessary to view training \& development from two different angles. The first view on training \& development considers the extent to which an organization provides opportunities for training \& development. On the other hand, the extent to which individuals actively engage and make use of these opportunities is important as well. Training \& Development should be accessible to all members of an organization, regardless of age. Research has shown that due to an intense focus on labour unions and policies on younger employees, organizations barely bring the promotion of training \& development possibilities for older workers into their focus (Armstrong-Stassen and Schlosser, 2008). 
Further, Bowen-Wilson (2001) point out that employers actually consider it difficult to provide senior employees with training \& development possibilities. A reason for this might be that employers do not value the intellectual capital and mental skills that senior employees bring to an organization, as indicated by Porcellato et al. (2010). As already mentioned, training \& development attempts can be hampered by two things, either a person's unwillingness for training \& development or a lack of training \& development possibilities. Several researchers showed that older workers demonstrate a lack of selfconfidence and a negative self-perception. They also report previous negative experiences with their classroom settings (Porcellato et al., 2010; Beck, 2014). According to Billett et al. (2011), this may have led to the conclusion that senior workers are unwilling to take part in training \& development activities. Training and Development is a crucial strategy to retain senior workers (Koc-Menard, 2009). Training and Development for senior workers can make sense in two ways. It can either renew critical skills or development skills which help employees to work during their transition time in a new position or function (Pitt-Catsouphes and Smyer, 2006).

Training \& development opportunities, even when provided in a small quantity, exert positive effects (Armstrong-Stassen and Schlosser, 2008; Ravichandran et al. 2015). Nevertheless, the purpose of participating in training \& development possibilities varies. While senior workers primarily want to meet external demands, younger employees strive for gains (Stamov-Roßnagel and Hertel, 2010). Hence, interest in training which is targeted at gaining skills, career advancements or knowledge, decreases with age. Furthermore, as demonstrated in a study by Zwick (2015), informal training in the form of on-the-job training or self-induced training (e.g. reading related literature) is more effective for senior workers than training in in-class settings (e.g. formal seminars or workshops).

\section{Promotion of health}

The main reasons for exiting the labour market are poor health conditions and disabilities. Those whose health forces them to exit the labour market before the legal retirement age often experience negative consequences, such as long-term unemployment and disruptions to their social well-being (Robroek et al., 2013). Research has shown that organizations that instituted health promotion interventions (addressed to psychosocial and physical health) were able to reduce risks while at the same time improving productivity in the workplace (Crawford et al., 2010). Aspects which are of importance for maintaining good health in the workplace can be either direct (e.g. regular health checks, promoting health awareness and health counselling practices) or indirect (e.g. positive working environment, good relationship with supervisor and co-workers and skills development).

It might be valuable to point out that several studies conflict the belief of an inability to work or an declining productivity with age. As indicated by a study of Sluiter and Frings-Dresen (2007), on the basis of secondary medical data and direct interviewing, the majority of jobs do not require early retirement (Griffin et al., 2012). Another study of Parkhouse and Gall (2004) further emphasizes the fact that there is rather no traceable relationship between increasing age and declining productivity. A similar study on the perception of performance and age, conducted by Morales and Marquina (2008), processed corresponding results.

\section{INCLUSIVE ATMOSPHERE AND AGE-DIVERSE GROUPS}

Very little research exists focusing on age diversity in the workplace. Compared to other diversity dimensions, employers rarely take initiative to promote age diversity. Therefore, research on age is much less developed than research on race or gender in the field of organizational research (Shore et al., 2009). However, the age management problem has increasingly infiltrated into scientific discourse (James et al., 2011). Inclusion and diversity are both emerging approaches in the organizational theory literature.

Inclusion by itself can be either understood as a "humans' innate curiosity" (Maslow, 1943), also called belongingness, the degree to which an individual feels as an esteemed member of a particular group (Shore et al., 2011). From the viewpoint of critical organizational processes, it reflects an extent to which an individual perceives to have access to information, connected- 
ness with supervisors and peers, and the ability to participate in decision making in their organization (Barak, 2000). Several studies outline values senior employees bring to an organization or team. Crosssectional, quantitative studies, such as performed by McCartney and Worman (2010) or Macleod et al. (2010) brought to light which positive factors employers relate rather to senior employees than to younger employees. These factors include knowledge and skills. Organizations profit from the competences of senior workers in terms of better mentoring, leading, coaching, better knowledge and understanding over business and organizational processes, problem-solving abilities, fewer mistakes and better understanding of customer needs. However, whether teams could benefit from values of senior workers is not a coincidence, but the consequence of age diversity management and proper age-diverse teams. The consequence of a proper functioning age-diverse team allows for complementing and extending a team's effectiveness, a better quality of work (Stankiewicz, 2015; Roberge and Dick, 2010) and increased job satisfaction (Rabl and Triana, 2014). However, as demonstrated by the already-mentioned research study by Stankiewicz (2015), conducted on a research sample of organizations in Poland, discrepancies between an organization's declared opinion (the organization is aware of benefits of age diversity management) and actions taken to form age-diverse teams (the organization creates an environment which enables to use the full potential of age-diverse teams) are apparent. The inconsistency of the result could be explained by a widespread social belief that age-diverse teams are beneficial and an legislative pressure on anti-discrimination rules.

\section{Demotivators for senior employees}

\section{Prevailing Negative STEReOTYPeS AND AGeISM}

Studies concerning the field of organizational research have identified several agerelated stereotypes (Hassell and Perrewe, 1996; Poulston and Jenkins, 2013), as well as their influence on employment practices (Conen et al., 2011; Cheung et al., 2010). Of course, not all prevailing stereotypes result in unequal treatment. However, they may create a sufficient foundation and conditions for age-related discrimination in organizations and workplace conflicts to flourish (Cappelli, 2010). Research showed that several stereotypes are a common restraint to hiring senior employees. These stereotypes include: a lack of creativity, difficulties in training senior employees, lack of flexibility, and challenges of senior employees to adapt to new technology (Bytheway, 1995). Although many stereotypes towards older workers exist, senior employees see themselves as anything but last resort employees (Billett et al., 2011).

According to Billett et al. (2011), senior employees report themselves as competent, productive and capable of adapting to new work requirements. Although ageism stereotypes and age discrimination can work both ways and impact senior workers and younger workers equally, research has shown that senior employees are affected to a greater extent than their younger counterparts in selection (Finkelstein et al., 1995) and in issues associated with lower performance (Avolio, Waldman and McDaniel, 1990). Senior employees seem to receive less opportunities for training and development (Cleveland and Shore, 1992). Another argument which provides restraints to the hiring of senior employees suggests that senior workers should leave the labour market and create space for younger entrants. Those arguments are usually underpinned by economic theories, like Human Capital Theory (Cavanagh, 2002).

To provide a solution to the complexity of this problem, many scholars still point to anti-discrimination legislation as a framework to address this issue (Herring, 2011; Neumark, 2003). Frameworks and policies which should maintain senior workers in employment are usually constructed on the superficial level of an organization. As major restraints preventing the hiring of older employees are rather based on inner beliefs and assumptions, a more profound organizational level should be addressed in order to ensure the effectiveness of such frameworks and policies. To improve these policies and practices, shifting employers' attitudes towards senior employees to recognize their full capabilities and potential is crucial. Hence, changing these negative attitudes and focusing on the strengths of senior employees (Barnett et al., 2008) can minimize stereotyping. 


\section{WORK STRESS}

A factor which has been identified to have a significant impact on the workability (the perceived mental and physical capacity to work) is work stress (de Zwart et al., 1999). Therefore, another aspect of successful maintenance of health in the workplace should address the job design and corresponding minimization of stress. A combination of high workload and low control can provoke stress (Wilson, 2000; Ahola et al. 2009). Researchers have identified a number of elements which are related to job design that significantly provoke work stress. Among these elements are role overload, role conflict, role ambiguity and lack of control over work (Blackburn, 2007). According to Herzog et al. (1991) and Reskin (2000), work stress is the main factor for reduced well-being and early retirement for senior employees. However, although training on work and workability was provided to managers and employees, there have been no visible results after a trail period of one year.

\section{REFRESHMENT OF JOB-RELEVANT HARD SKILLS}

Psychological and medical studies have demonstrated that during the course of one's life, certain abilities tend to decrease as age increases (Kalwij and Vermulen, 2008). This view is also supported by the OECD which claims that at an age of 35 years of age, our cognitive abilities peak. Afterwards, these cognitive abilities decrease as a person ages (WEF, 2016). On the other hand, several studies also pointed out that while some cognitive abilities might decrease, others are stable or even improve with age (Arking, 2006). According to Turek and Perek-Bialas (2013), a major asset of senior employees is experience: job knowledge, practical knowledge, tacit knowledge and expertise. Following their arguments, experience and crystallized abilities (e.g. knowledge and skills, reading comprehension, the ability to retrieve familiar information and verbal skills) do not deteriorate with age (Horn, 1967; Skirbekk, 2008). Therefore, experience helps senior employees in dealing with tasks and diagnosing mechanisms which rule the work setting and its environment. On the other hand, scholars recognized a lack in new work settings, rapid changes and new technology, which were also reported by Munnell and Sass (2008). According to Turek and Perek-Bialas (2013) study's results, senior workers score highly on soft skills such as loyalty, reliability, management and social skills, but have shortcomings in skills using new technology, creativity and flexibility (hard skills). As older employees continue to age, there is a need for lifelong learning which aims at improving hard skills. It is necessary for organizations to update and improve these hard skills, particularly new technology skills, and to develop a sense and ability to learn in the later stages of one's career.

\section{Discussion of the literature review}

Although age management has been on the research agenda for several years, there are insufficient findings on sharing best practices. So far, a relatively large number of organizational initiatives are observable, but knowledge on good practices is still limited. A greater benefit could probably be achieved if a few practices could be identified for broader implementation, systematic evaluation and monitoring via a close dialogue between employers and scholars. The ageing of the population calls for a two-sided approach: first to promote the employability of senior workers and then to reduce or eliminate challenges which employees may face in the later stages of their career. On the basis of the conducted literature review, several elements could be identified that are crucial for an agefriendly workplace. The literature review identified several useful practices and strategies towards senior employees.

Altogether, they could be labelled as motivators for senior employees to continue working, depending on the presence (e.g. valuable source of labour, flexible workplace, job design options, ergonomically designed work places, culture of inclusion, organizational support, training and development) or absence of these factors (e.g. age discrimination, prevailing negative stereotypes, work stress and lack of training on hard skills) in the work setting. However, no evidence on how these elements correlate with each other exists. 


\begin{tabular}{|l|l|}
\hline \multicolumn{2}{|c|}{ Creating an age-friendly workplace } \\
\hline \multicolumn{1}{|c|}{ Presence of } & \multicolumn{1}{c|}{ Absence of } \\
\hline Job/organizational related factors & Job/organizational related factors \\
- Flexible work design options & - Negative stereotypes \\
- Training \& Development possibilities & - Poor work environment/work stress \\
- Promotion of Health & - Age discrimination \\
- Supportive and inclusive atmosphere & (hard and soft age discrimination) \\
- Age-diverse groups & - Recurring refreshment of job relevant hard skills \\
\hline
\end{tabular}

Source: own elaboration.

Conen et al. (2012) propose the presence of flexible job design options and training and development possibilities. Among age-friendly organizational factors which should be present, scholars frequently name ergonomically designed workplaces, health promotion and agediverse group compilation, creating a supporting and inclusive atmosphere. On the other hand, an environment which could be hostile towards senior employees can be caused by prevailing negative stereotypes, forms of age discrimination, work stress and a lack of renewal of job relevant hard skills.

While we can describe them as single factors, research indicates that a single factor will not be responsible for the motivation or demotivation of senior employees it is the combination of those factors. This view is supported by scholars who claim that while organizations might have implemented several age-friendly job-related factors, these factors will not be effective due to their availability alone. For example, Thompson et al. (1999) argue that flexible workplace policies are not used without support and active promotion on the management level. Furthermore, ArmstrongStrassen and Ursel (2009) demonstrated that senior workers feel supported by the availability of training and development options. Consequently, if an organization does not view senior workers as a valuable source of labour, it will not provide training and development options for senior employees. Moreover, the presence of age discrimination in the workplace negatively impacts the intention to provide senior employees with training and development options. Besides, it has a negative impact on perceived organizational support, fair- ness, recognition and inclusion (Pless and Maak, 2004). However, the same studies (e.g. Armstrong-Strassen and Ursel, 2009; Lockwood, 2007; Pless and Maak, 2004) also illustrate that targeting a rather superficial factor in an organization may prove insufficient when shaping a systematic approach to create an age-friendly workplace. Senior employees comprise a growing share of today's workforce. Entrepreneurs are still in the starting phase of focusing on the benefits and challenges of an ageing workforce.

\section{References}

Ahola, K., Gould, R. and Virtanen, M. (2009). Occupational burnout as a predictor of disability pension: a population-based cohort study. Occupational and Environmental Medicine, 66(5), 284-290.

Appannah, A. and Biggs, S. (2015). Age-Friendly Organisations: The Role Of Organisational Culture and the participation of older workers. Journal of Social Work Practice, 29(1), 37-51.

Armstrong-Stassen, M. (2008). Organisational practices and the post-retirement employment experience of older workers. Human Resource Management Journal, 18, 36-53.

Armstrong-Stassen, M. and Templer, A. (2005). Adapting training for older employees: the Canadian response to an aging workforce. Journal of Management Development, 24, 57-67.

Armstrong-Stassen, M. and Schlosser, F. (2008). Benefits of a supportive development climate for older workers. Journal of Managerial Psycholoy, 23(4), 419-437.

Armstrong-Stassen, M. and Ursel, N.D. (2009). Perceived organizational support, career satisfaction, and the retention of older workers. Journal of Occupational and Organizational Psychology, 82, 201-220. 
Avolio, B., Waldman, D. and McDaniel, M.A. (1990). Age and work performance in nonmanagerial jobs: the effects of experience and occupational type. Academy of Management Journal, 33, 407-422.

Bal, M.P., Kooij, D. and Rousseau, D. (eds.) (2015). Aging Workers and the Employee-Employer Relationship. Springer: Switzerland.

Barak, M.E.M. (2000). The inclusive workplace: an ecosystems approach to diversity management. Social Work, 45, 339-353.

Barnett, K., Spoehr, J. and Parnis, E. (2008). Exploring the Impact of an Ageing Workforce on the South Australian Workers' Compensation Scheme: Good practice in workplace age management. The South Australian Work Cover Corporation.

Beck, V. (2014). Employers' views of learning and training for older workers. Management Learning, 45(2), 200-215.

Becker, G.S. (1957). The Economics of Discrimination. University of Chicago Press: Chicago.

Beehr, T.A. and Bennett, M.M. (2015). Working After Retirement: Features of Bridge Employment and Research Directions. Journal of Working, Aging and Retirement, 1(1), 112-128.

Billett, S., Dymock, D. and Johnson, G. (2011). Overcoming the paradox of employers' views about older workers. International Journal of Human Resource Management, 22(6), 1248-1261.

Blackburn, R. (2007). Age Shock: How Finance is Failing Us. Verso: London.

Buyens, D., Van Dijk, H., Dewilde, T. and De Vos, A. (2009). The aging workforce: perceptions of career ending. Journal of Managerial Psychology, 24(2), 102-117.

Bytheway, B. (1995). Ageism: Rethinking Ageing. Open University Press: Philadelphia.

Cappelli, P. (2010). New Workforce Management: The Aging Workforce and the Reversal of Authority. Available on: http://hiring.monster.com/hr/ hr-best-practices/workforce-management/hr-management-skills/new-workforce-management.aspx (21.01.2018).

Cavanagh, M. (2002). Against Equality of Opportunity. Oxford: Oxford University Press.

Cheung, C., Kam, P.K. and Ngan, R.M. (2010). Age discrimination in the labour market from the perspectives of employers and older workers. International Social Work, 54, 118-136.

Claes, R. and Heymans, M. (2008). HR professionals' views on work motivation and retention of older workers: a focus group study. Career Development International, 13, 95-111.

Cleveland, J.N., and Shore, L.M. (1992). Self and supervisory perspectives on age and work attitudes and performance. Journal of Applied Psychology, 77, 469-484.
Conen, W.S., Henkens, K. and Schippers, J.J. (2011). Are employers changing their behavior toward older workers? An analysis of employers' surveys 2000-2009. Journal of Aging \& Social Policy, 23, 141-158.

Conen, W.S., Henkens, K. and Schippers, J. (2012). Employers' attitudes and actions towards the extension of working lives in Europe. International Journal of Manpower, 33(6), 648-665.

Crawford, J.O., Graveling, R.A., Cowie, H. and Dixon, K. (2010). The health safety and health promotion needs of older workers. Occupational Medicine, 60, 184-192.

Czakon, W. (2011). Metodyka systematycznego przeglądu literatury. Przeglad Organizacji, 3, 57-61.

de Zwart, B.C.H., Frings-Dresen, M.H.W. and van Duivenbooden, J.C. (1999). Senior workers in the Dutch construction industry: A search for agerelated work and health issues. Experimental Aging Research, 25(4), 385-391.

Dustmann, C.H. and Meghir, C. (2003). Wages, experience and seniority. The Review of Economic Studies, 72(1), 77-108.

Eurostat (2017). People outside the labour market. Available at: http://ec.europa.eu/eurostat/statisticsexplained/index.php/People_outside_the_labour_ market (17.08.2018).

Eversole, B., Venneberg, D.L. and Crowder, C.L. (2012). Creating a Flexible Organizational Culture to Attract and Retain Talented Workers Across Generations. Advances in Developing Human Resources, 14(4), 607-625.

Edwards, J.R., Cable, D.M., Williamson, I.O., Lambert, L.S. and Shipp, A.J. (2006). The phenomenology of fit: linking the person and environment to the subjective experience of personenvironment fit. Journal of Applied Psychology, 91(4), 802-827.

Finkelstein, L.M., Burke, M.J. and Raju, N.S. (1995). Age discrimination in simulated employment contexts: an integrative analysis. Journal of Applied Psychology, 80, 40-45.

Flabbi, L. and Ichino, A. (2001). Productivity, seniority and wages: new evidence from personnel data. Labour Economics, 8(3), 359-387.

Fuller, A., Hodkinson, H., Hodkinson, P. and Unwin, L. (2005). Learning as peripheral participation in communities of practice: a reassessment of key concepts in workplace learning. British Educational Research Journal, 31(1), 49-68.

Griffin, B., Hesketh, B. and Loh, V. (2012). The influence of subjective life expectancy on retirement transition and planning: A longitudinal study. Journal of Vocational Behavior, 81(2), 129-137.

Hamermesh, D.S. (1993). Labor Demand. Princeton. New Jersey: Princeton University Press. 
Hassell, B.L. and Perrewe, P.L. (1995). An examination of beliefs about older workers: do stereotypes still exist?. Journal of Organizational Behavior, 16(5), 457-468.

Henkens, K. (2005). Stereotyping Older Workers and Retirement: The Managers' Point of View. Canadian Journal on Aging, 24, 35-48.

Herrbach, O., Mignonac, K., Vandenberghe, C. and Negrini, A. (2009). Perceived HRM practices, organizational commitment, and voluntary early retirement among late-career managers. Human Resource Management, 48(6), 895-915.

Herring, J. (2011). Age discrimination and the law: Forging the way ahead. In: P. Emma and T. Shaun (eds.), Managing Age-diverse Workforce. Basingstoke: Palgrave Macmillan.

Hertel, G., van der Heijden, B., de Lange, A.H. and Deller, J. (2013). Facilitating age diversity in organizations - part II: managing perceptions and interactions. Journal of Managerial Psychology, 28(7/8), 857-866.

Herzog, A., House, J.S. and Morgan, J.N. (1991). Relation of work and retirement to health and well-being in older age. Psychology and Aging, 6, 202-211.

Hilton, J.L. and Von Hippel, W. (1996). Stereotypes. Annual Review of Psychology, 47, 237-271.

Hutchens, R. (1987). A test of Lazear's theory of delayed payment contracts. Journal of Labour Economics, 5(4), 153-170.

ILO (2011). Germany: A job-centered Approach. Studies on Growth and Equity. ILO: Geneva.

James, J.B., McKechnie, S. and Swanberg, J. (2011). Predicting employee engagement in an agediverse retail workforce. Journal of Organizational Behavior, 32(2), 173-196.

Joulain, M. and Mullet, E. (2001). Estimating the "Appropriate" Age for Retirement as a Function of Perceived Occupational Characteristics. Work \& Stress, 15, 357-365.

Koc-Menard, S. (2009). Training strategies for an aging workforce. Industrial and Commercial Training, 41(6), 334-338.

Krecker, M.L. (1994). Work Careers and Organizational Careers - The Effect of Age and Tenure on Worker Attachment to the Employment Relationship. Work and Occupations, 21(3), 251-283.

Latack, JC. (1986). Coping with job stress: measures and future directions for scale development. Journal of Applied Psychology, 71(3), 377-385.

Lazear, E.P. (1979). Why is there Mandatory Retirement? Journal of Political Economy, 87, 1261-1274.

Leifels, A. (2016). Older workers in SMEs - a golden asset or a liability? KfW Research Focus on Economics, No. 122, KfW SME Panel 2014.
Macleod, A., Worman, D., Wilton, P., Woodman, P. and Hutchings, P. (2010). Managing an ageing workforce - How employers are adapting to an older labour market. Chartered Management Institute (CMI), September 2010, United Kingdom.

McCann, R. and Giles, H. (2003). Ageism in the Workplace: a Communication Perspective. In: T.D. Nelson (eds.), Ageism, Stereotyping and Prejudice Against Older Persons. Cambridge: MIT Press.

McCartney, C. and Worman, D. (2010). The value of mature workers to organisations in Singapore. Chartered Institute of Personnel and Development (CIPD), Survey report, May 2013, United Kingdom.

Maslow, A.H. (1943). A theory of human motivation. Psychological Review, 50(4), 370-396.

Mincer, J. (1958). Investment in human capital and personal income distribution. The Journal of Political Economy, 66(4), 281-302.

Montenegro, X., Fisher, L. and Remez, S. (2002). Staying ahead of the curve: The AARP work and career study conducted for AARP by Roper ASW. American Association of Retired Persons: Washington, DC.

Morales, C. and Marquina, P. (2008). Evidence on the role of age in team performance: A comparative study in Peru and Spain. Employee Relations, 31(3), 264-275.

Neumark, D. (2003). Age Discrimination Legislation in the United States. Contemporary Economic Policy, 21(3), 297-317.

OECD (2015). Working Better with Age Poland: Assessment and main recommendations. Directorate for Employment, Labour and Social Affairs, March 2015.

Parkhouse, W. and Gall, B. (2004). Changes in physical capacity as a function of age in heavy manual work. Ergonomics, 47(6), 671-687.

Paul, R.J. and Townsend, J.B. (1993). Managing the older worker - don't just rinse away the grey. The Academy of Management Executive, 7, 67-74.

Phelps, E.S. (1972). The Statistical Theory of Racism and Sexism. American Economic Review, 62, 659-661.

Pitt-Catsouphes, M. and Smyer, M. (2006). One Size Doesn't Fit All: Workplace Flexibility. Issue Brief 5, Center on Aging \& Work, Chestnut Hill, MA.

Pless, N. and Maak, T. (2004). Building an inclusive diversity culture: Principles, processes and practice. Journal of Business Ethics, 54, 129-147.

Porcellato, L., Carmichael, F., Hulme, C., Ingham, B. and Prashar, A. (2010). Giving older workers a voice: Constraints on the employment of older people in the North West of England. Work Employment and Society, 24(1), 85-103.

Poulston, J. and Jenkins, A. (2013). The Persistent Paradigm: Older Worker Stereotypes in the 
New Zealand Hotel Industry. Journal of Human Resources in Hospitality \& Tourism, 12, 1-25.

Rabl, T. (2010). Age, discrimination and achievement motives - A study of German employees. Personnel Review, 39(4), 448-467.

Rabl, T. and Triana, M.C. (2014). Organizational Value for Age Diversity and Potential Applicants' Organizational Attraction: Individual Attitudes Matter. Journal of Business Ethics, 121, 403-417.

Rau, B.L. and Adams, G.A. (2005). Attracting retirees to apply: Desired organizational characteristics of bridge employment. Journal of Organizational Behavior, 26, 649-660.

Ravichandran, S., Cichy, K.E., Powers, M. and Kirby, K. (2015). Exploring the training needs for older workers in the foodservice industry. International Journal of Hospitality Management, 44, 157-164.

Remery, C., Henkens, K., Schippers, J. and Ekamper, P. (2003). Managing an aging workforce and a tight labor market: Views held by Dutch employers. Population Research and Policy Review, 22, 21-40.

Reskin, B.F. (2000). The proximate causes of employment discrimination. Contemporary Sociology, 29, 319-328.

Roberge, M.E. and Dick, R. (2010). Recognizing the benefits of diversity: when and how does diversity increase group performance? Human Resource Management Review, 20, 295-308.

Robroek, S.J., Schuring, M., Croezen, S., Stattin, M. and Burdorf, A. (2013). Poor health, unhealthy behaviors, and unfavorable work characteristics influence pathways of exit from paid employment among older workers in Europe: a four year followup study. Scandinavian Journal of Work, Environment \& Health, 39, 125-133.

Rudolph, C., de Lange, A. H. and van der Heijden, B.I.J.M. (2014). Adjustment processes in bridge employment: Where we are and need to go. In: P.M. Bal, T.A.M. Kooij and D. Rousseau (eds.), Aging Workers and the Employee-Employer Relationship. Springer: New York.

Serban, A.C. (2012). Aging population and effects on labour market. International Conference On Applied Economics (ICOAE) 2012.

Shore, L.M., Chung-Herrera, B.G., Dean, M.A., Erhardt, K.H., Jung, D.I., Randel, A.E. and Singh, G. (2009). Diversity in organizations: Where are we now and where are we going?. Human Resource Management Review, 19, 117-133.

Shore, L.M., Randel, A.E., Chung, B.G., Dean, MA., Ehrhart, K.H. and Singh, G. (2011). Inclusion and diversity in work groups: A review and model for future research. Journal of Management, 37, 1262-1289.
Sluiter, J. K. and Frings-Dresen, M.H.W. (2007). What do we know about ageing at work? Evidencebased fitness for duty and health in fire fighters. Ergonomics, 50(11), 1897-1913.

Stamov-Roßnagel, C. and Hertel, G. (2010). Older worker's motivation: against the myth of general decline. Management Decision, 48(6), 894-906.

Stankiewicz, K. (2015). Value of Age Diversity - Declarations and Practice in Polish Organizations. Social Sciences, 3(89), 19-32.

Thompson, C.A., Beauvais, L.L. and Lynessa, K.S. (1999). When work-family benefits are not enough: The influence of work-family culture on benefit utilization, organizational attachment, and workfamily conflict. Journal of Vocational Behaviour, 54, 392-415.

Tros, F. (2005). Flexicurity and HR-strategies for the older workers: A comparative appraisal of four European countries. Managing Social Risk Through Transitional Labour Markets, Working Paper, May 2005.

Turek, K. and Perek-Bialas, J. (2013). The role of employers opinions about skills and productivity of older workers: example of Poland. Employee Relations, 35(6), 648-664.

Thurow, L.C. (1975). Generating Inequality. New York: Basic Books.

Van Beek, K.W.H., Koopmans, C.C. and van Praag, B.M.S. (1997). Shopping at the Labor Market: a Real Tale of Fiction. European Economic Review, 41, 295-317.

Van Dalen, H.P. and Henkens, K. (2005). The Double Standard in Attitudes toward Retirement - the Case of the Netherlands. Geneva Papers of Risk and Insurance - Issues and Practice, 30, 693-710.

Van der Heijden, B.I.J.M., Schalk, R. and van Veldhoven, M.J.P.M. (2008). Ageing and careers: European research on long-term career development and early retirement. Career Development International, 13(2), 85-94.

Wang, M. and Schultz, K.S. (2010). Employee retirement: a review and recommendations for future investigation. Journal of Management, 36(1), 172-206.

Wilson, E. (2000). Inclusion, exclusion and ambiguity - the role of organisational culture. Personnel Review, 29, 274-303.

Wilthagen, T. (2001). The transitional Labor Market and Flexicurity (De transitionele arbeidsmarkt en flexicurity). In: N. van den Heuvel et al. (eds.), The Transitional Labour Market: Contours of an Active Labour Market Policy (De transitionele arbeidsmarkt. Contouren van een actief arbeidsmarktbeleid). Den Haag: Elsevier.

World Economic Forum (WEF) (2016). Shaping the Global Agenda on Ageing: Meeting the Needs of 
Cognitive Decline. REF 290716. Available at: http:// www3.weforum.org/docs/WEF_Meeting_Needs_ Cognitive_Decline_070916.pdf (28.08.2018).

Yeatts, D.E., Folts, W.E. and Knapp, J. (2000). Older workers' adaption to a changing workplace:
Employment issues of the 21st century. Educational Gerontology, 26, 565-582.

Zwick, T. (2015). Training older employees: what is effective? International Journal of Manpower, 36(2), $136-150$. 